\title{
Macromycetes of oak-hornbeam forests in the Białowieża National Park - monitoring studies
}

\author{
ALINA SKIRGIELLO
}

Institute of Botany, University of Warsaw

Al. Ujardowsk ie 4, PL-00-478, Warszawa, Poland

$\mathrm{Sk}$ i $\mathrm{g} \mathrm{g}$ ie 110 A. Macromyceles of aak-hormbean forosts in the Bialowieza National Park - monitoring studies. Acta Mycol. 33 (2): 171-189, 1998.

Mycosociological observations were carried out between 1994-1996 on permanent plots within a Tilio-Carpinetum association in the Bialowieża National Park. The project was carried out with international cooperation within the "Mycological monitoring in European oak forests" programme which was a result of multiple signals concerning the disappearance of oaks in our continent. Almost 40 years before mycosociological research in the same plant association and at the same plots were carried out. Studies were mainly concerned with analysing the terrestrial macromycetes, predominantly Boletales and Agaricales. They analysed the occurrence of saprotrophic and mycorthizal fungi. Totaly 215 species from the above listed ecological groups, but there were only 34 species common to both studies. Dominating species within the mycorrhizal group were found.

Key words: myeological monitoring, disappearanee of oaks, Boletales, Agaricales.

\section{INTRODUCTION}

In 1992, during a meeting of mycologists, a project was conceived to carry out a monitoring programme for some groups of fungi in Europe. The idea emerged during a discussion concerning the disappearance of oak trees in various countries, including Poland. Reasons for this decline were sought for among environmental conditions, amongst others the negative influence of parasitic fungi. Interference by so-called "terrestrial fungi" was also suggested, since their fruit-bodies are found near trees which constitute their mycorrhizal partners. And there are difficulty in carrying out respective studies. Trees take many years to grow, whereas fruit-bodies appear sporadically, although their mycelium develops and lives in the soil. The disappearance of oak trees has been observed for many years, but nothing indicated any association of 
this phenomenon with the species of macromycetes fruit-bodies found. Among them a group of fungi stands out, consisting of species that only attack weakened parts of plants and develop only on dead parts (twigs, leaves). This group includes some endophytic fungi, the presence of which cannot be detected in the infected over-ground organs that do not show any pathological changes ( $\mathrm{P}$ r z y b y $\mathrm{f}$ 1995). Hence the question emerged as to whether the perceived appearance of macromycetes fruit-bodies near oak trees can to some extent reflect the state of health of those economically important trees, or not.

Poland was among those countries that undertook the three-year long fungi monitoring programme. Our country, situated in the central part of Europe and covered in forests where Quercus robur is one of the most common forest tree species, was established as the north-eastern border of the study area. The Bialowieża Forest, being the largest (62 500 ha) continuous forest complex with variously distributed mosaic of plant associations in Central Europe, was considered to be one of the most suitable study objects. Within the complex, which constitutes a relatively well-preserved monument of natural plant communities, a large fragment (5 $346 \mathrm{ha}$ ) was established as a National Park with the characteristics of a nature reserve in 1921. The Park's value was recognised by the World Health Organisation which included it in the clean biosphere zone in 1977 .

Several researchers penetrated the Park's area before it was established, studying its mycogeography by walking through it (B l o n s $\mathrm{k}$ i et al. 1888; B to n s k i and D r y m m e 1889). Between 1959 and 1978 more regular studies were carried out by Dominik, Domański (see S k i r g i e 1 o 1988). The latter study was dominated by taxonomic issues. A new direction in mycology, fungi sociology, was reflected in by studies $\mathrm{N}$ es p i a k studies $(1955,1959)$, who was the first to publish an extensive report of the results of his research in several plant associations within the Park.

Nespiak's study was, to a certain extent, continued by the CRYPTO programme, initiated by Faliniski and carried out by a group of specialists. The aim of this undertaking was to survey cryptogamous plant communities in six main forest associations of the National Park, in the area of approximately 144 ha (F a li ńs ki and $\mathrm{Mufenk} \mathrm{o} \mathrm{1992).} \mathrm{Almost} \mathrm{simultaneously,}$ scientists undertook international cooperation within the mycological monitoring programme, in oak forests in several regions of Poland.

The monitoring programme required its participants to carry out stationary studies on permanent study plots within one association. In the face of reports coming from all over Europe, concerning the disappearance of oak trees, Tilio-Carpinetum Tracz. 1962 was selected since both those trees and mycorrhizal fungi can be found there. Polish mycologists designed the study in several forest complexes situated at distances from each other where this type 
of forest prevails. The Bialowieża National Park, a large area, the most north-easterly situated of those in our country, was selected as one of them. Nespiak's first mycosociological observations were carried out there 40 years ago, which was another argument for such a choice. It should be expected that changes may have happened in the macromycetes community during such a long period.

\section{METHODS}

The study methods were very similar to those of Nespiak, which ensured the possibility of making comparisons. I was interested in observing changes that may have occurred in the macromycetes community in 40 years, in a forest where the oak had a large share, while Nespiak intended to investigate the diversity of fungi in various communities. Nespiak established his study plots (usually two) in each plant association. I established my study plots in two neighbouring forest divisions, at a distance of about $1.5 \mathrm{~km}$ apart. One of the plots was located in a subassociation Tilio-Carpinetum typicum (I) and the other in Tilio-Carpinetum stachyetosum (II). Collected specimens are preserved in the Herbarium of the University of Warsaw (WA).

I carried out my studies between 1994 and 1996 in divisions 370 and 399 . which were the same ones that Nespiak penetrated. With difficulty I managed to find his old study plots $\left(100 \mathrm{~m}^{2}\right)$. I established two (I and II) new, ten times larger $\left(1000 \mathrm{~m}^{2}\right)$ plots there. I divided each plot into ten $100 \mathrm{~m}$ squares and I drew sketches of the location of trees and fallen logs (Fig. 1). Observations and material collecting were carried out 6 times during the vegetation period (May-October). Notes concerned the number of fruit-bodies in each square, the number of denoting each species and all comments concerning the ground. The fruit-bodies had to be big enough to be detected by the unaided eye (i.e. more than $1 \mathrm{~mm}$ ). Therefore they included not only Basidiomycetes, but also some Ascomycetes. Nespiak, who was mainly interested in macromycetes carried out his observations in much the same way.

\section{STUDY AREA}

A comparison of the general picture of the plots from the old study and the present one doesn't show many differences. All plots are characterised by flat, even areas, they are dry and easily accessible throughout the vegetation period. Their soils can be described as brown forest soil on a bed of sand or boulder clay, with a pH of 4.59 (I) and 5.76 (II). Both plots differ slightly in their $\mathrm{pH}$ level; the former one being more acidic, with a lower 
A. Skirgiello

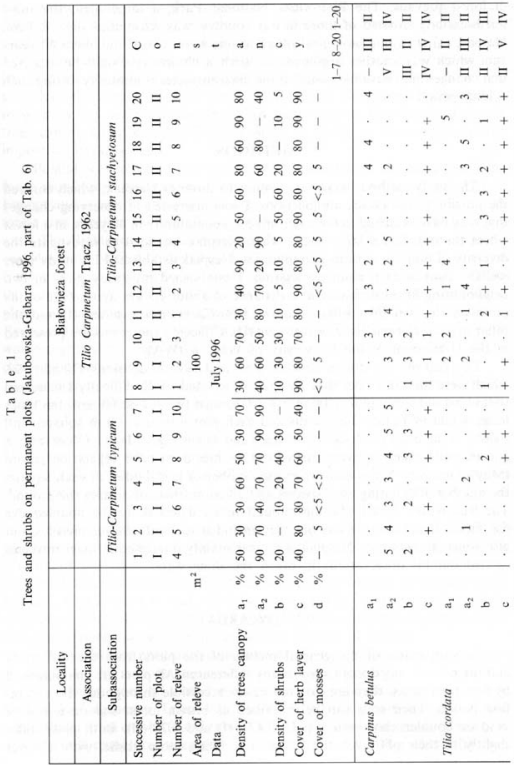




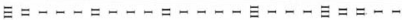

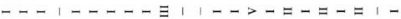

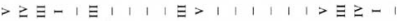
$n$

$r+$

$\mathrm{N}+\ldots+$

$++$

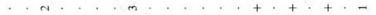

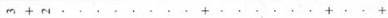

$-+.+\cdots+\cdots++\cdots+\cdots$

$\mathrm{n}+\ldots+\ldots+\ldots+\ldots++,+\cdots$

$m+\ldots++\ldots++\ldots++++$

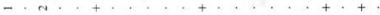

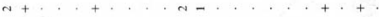

$m+\cdots++\ldots+++++++$

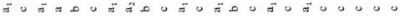

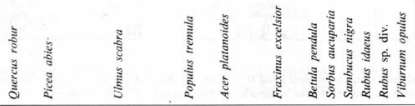




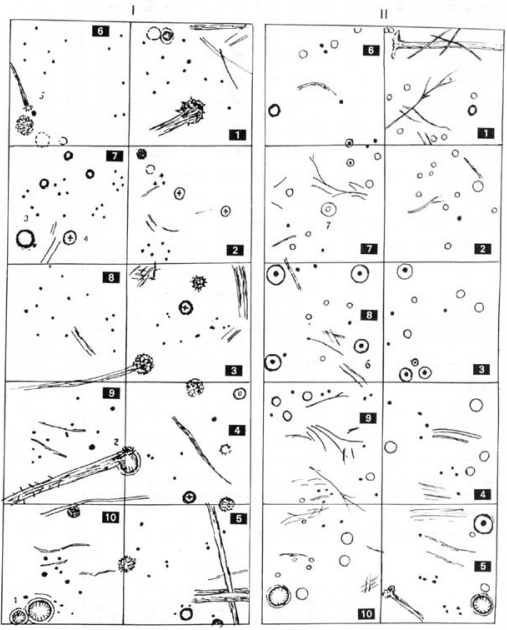

Fig. 1. Living and dead trees on the plots 1 and 11: 1. Quercus robur, 2. Picea abies, 3. Ulmas scubra, 4. Carpinus betulus, 5. Sorbus aucuparia, 6. Tilia cordata, 7. Acer platanoides 
$\mathrm{pH}$ than the latter. In his studies, Nespiak found a slightly wider range of $\mathrm{pH}$ values, i.e. from 4.8 to 6.5 , which is slightly closer to the neutral level. The forest floor is covered by a thick layer of leaf litter. It is relatively thin under old oak trees and it is not covered by herbaceous vegetation or mosses. All types of dry-ground forests are dominated by hornbeam accompanied by oak, linden and spruce (Tab. 1). In this case the spruce doesn't enter the association.

\section{Plot I}

The relatively shady plot $\mathrm{I}$ includes 4 large oaks. Two of them are situated deep in its central part and the other, older (more than 200 years) two are on a bank of a small forest marsh which is partially situated within the plot (Fig. 1). During drier years its water table decreases and the surface is covered in duckweed, while rushes develop at its edge. The fifth oak tree, which is not considered here, is located just outside the plot. It is periodically flooded and infected with Fomes fomentarius.

The density of the canopy of oaks and young, although tall hornbeams, as well as the bushy undergrowth cause relatively high shading of the ground $(30-70 \%)$. Oak seedlings are not numerous there. Herbaceous plants are mainly represented by Anemone nemorosa, Oxalis acetosella and Maianthemum bifolium. Several slightly decomposed logs and branches, as well as three humified spruce trunks, a decaying birch $\log$ and a fallen mountain ash, mouldy near its roots, complete the picture of the plot's arborescent vegetation.

\section{Plot II}

Plot II is more intensively green than plot I. It has a younger tree stand, more undergrowth, less thick, decaying logs, but more thin branches, more air current and light, as well as denser ground flora providing better conditions for fungi to thrive. The al layer contains less young, as well as old oak and hornbeam trees. The canopy is not so dense, which gives light more access to the ground than on plot I. The plot's location also has an influence on the light penetration. The plot is situated on the edge of the Bialowieza Primeval Forest, close to an agricultural field which is not extensively used. Sun rays penetrate the trunk wall from this dircction and the winds coming from the open area have an influence on drying the forest litter. Several mature maple and elm trees are situated right outside the plot. The $a_{2}$ layer includes quite a lot of young and little-branched lindens, particularly in the northern part of the square. The forest ground is much more densely covered by herbaceous vegetation than within plot I. Impatiens nolitangere, Paris quadrifolia and Ramunculus lanuginosa can be found there, while Stellaria holostea, 
Galium odoratum, Oxalis acetosella and Urtica dioica are everywhere. Forest animals, such as roe and red deer, as well as wild bores disturb the plots by turning over fallen branches and destroying the forest floor.

\section{RESULTS AND DISCUSSION}

\section{Comparisen of the collections}

While working on the mycosociology of the Biatowieza National Park $\mathrm{N}$ e s p i a k (1959) concentrated his studies on analysing species that have short-lived, fleshy fruit-bodies, mainly of the orders Boletales and Agaricales, since he was afraid of making mistakes resulting from repeating the collection. Therefore, there is no proper reference material concerning Aphyllophorales with perennial fruit-bodies which remain in the forest for a long time or the small Discomycetes and Pyrenomycetes.

Our comparisons of the species composition indicate that almost $3 / 4$ of Ascomycetes found in the previous study occurred on plots 1 and II. All of them are saprotrophes. Bisporella citrina (abundance $5 /$ frequency V) whose fruit-bodies locally occur in large numbers is worth noting, as well as Xylaria longipes ( $\mathrm{ab} 4 / \mathrm{fr} \mathrm{III})$, frequently referred to as $X$. polymorpha. The former dominated in plot II (700 individuals in June) and the latter in May (113 individuals). Both these fungi had seasonal fruit-bodies that occurred in clusters. The randomly occurring Laccaria laccata and Lactarius quietus were also among dominating species in 1996.

Amongst the 29 representatives of Aphyllophorales there were four well known tree parasites - Fomitopsis pinicola that grows on spruce trees, as well as Fomes fomentarius, Ganoderma lipsiense and Polyporus squamosus which grow on deciduous trees. Other species, whose fruit-bodies were smaller and which occurred individually thrived on small, fallen and partially decayed twig fragments. Only Schizopora paradoxa occurred numerously on the moist twigs laying on the forest floor in 1995 when it stopped its competitors from developing. It was almost gone by the following year.

Within both of the studied divisions Nespiak found 109 species of fungi, while I found twice as many, i.e. 215 species (Tab. 2). I shortened my collection list largely by reducing the species which were not included in his analysis. The eventual list contained 175 names. This revealed a 5:1 ratio in favour of the years 1994-1996, since 34 species were considered common, i.e. found in Nespiak's studies as well as in the current one, 40 years later. 
T a ble 2

Collected species with number of fruit-bodies found during the three-year researches (1994-1996)

\begin{tabular}{|c|c|}
\hline Species & Number of fruit-bodies \\
\hline 1 & 2 \\
\hline Bisporelka cirrina (Batsch: Fr.) Korf et Carp. & 2225 \\
\hline Stereum hirutum (Wilb: Fr.) S, F. Gray & 732 \\
\hline Mollisia cinerea (Batsch ex Merat) Karst. & 686 \\
\hline Dasyscypines virginews S. F. Gray & 650 \\
\hline Xylaria longipes Nitschke & 650 \\
\hline Armillaria mellea Fr. s.l. & 478 \\
\hline Xylaria hypoxylon (L.: Fr.) S. F. Gray & 289 \\
\hline Lactarias quietus $\mathrm{Fr}$. & 238 \\
\hline Collybia butyracea (Bull.: Fr.) Quél. & 219 \\
\hline Crepidons variabilis (Pers: Fr.) Quel. & 216 \\
\hline Kuehneronyces matabilis (Schaeff: Fr.) Sing et Smith & 200 \\
\hline Inonotus rheades (Pers) Bond. et Sing. & 186 \\
\hline Collybia peronata (Bolt:: Fr.) Sing. & 168 \\
\hline Lycoperdon pyriforme Schaeft. Pers. & 157 \\
\hline Lycoperdan perhatum Pers.: Pers. & 156 \\
\hline Paxillus involutus (Batsch) Fr. & 151 \\
\hline Hypoxylon fragiforme (Pers.: Fr.) Kickx & 139 \\
\hline Fomes fomentarius (L.: Fr.) Kickx & 135 \\
\hline Schizopora paradoxa (Schrad: Fr.) Donk & 124 \\
\hline Hypholoma sublateritium (Pers.) Quél. & 123 \\
\hline Dacrymyces stillatus Nees.: Fr. & 111 \\
\hline Coprinus desseminatus (Pers.) S. F. Gray & 110 \\
\hline Hypholoma subviride (Berk. et Curt) Dennis & 98 \\
\hline Fomitopsis pinicola (Sw:- Fr.) P. Karst. & 94 \\
\hline Mycena filopes (Bull.) Kummer non ss, Ricken & 94 \\
\hline Clitocybe clavipes (Pers.: Fr.) Kummer & 86 \\
\hline Ganoderma lipsiense (Batsch) Atk. & 85 \\
\hline Rickenella fibula (Fr.) Raith. & 84 \\
\hline Laccaria laceata (Scop.: Fr.) Berk. et Br. & 78 \\
\hline Lactarius mitissimus ( $\mathrm{Fr}_{\mathrm{r}}$ ) $\mathrm{F}_{\mathrm{r}}$ & 76 \\
\hline Bjerkandera adusia (Willd.: Fr.) Karst. & 75 \\
\hline Exidia plana (Wigg ex Schlecht.) Donk & 75 \\
\hline Mycena maculata Karst. & 71 \\
\hline Mycena tintànabudum (Fr) Qućl. & 70 \\
\hline Rusula achroleuca (Pers.) Fr. & 67 \\
\hline Collybia confitiens (Pers: Fr.) Kummer & 64 \\
\hline Lepista mada (Bull: Fr) Cook & 61 \\
\hline Mycena polygramma (Bull.: Fr.) S. F. Gray & 58 \\
\hline Sirobilurus esculentus (Wulf: Fr.) Sing. & 58 \\
\hline Mycena vitilis (Fr.) Quél. & 56 \\
\hline Mollisia discolor (Mont.) Le Gal & 55 \\
\hline Pluteus cervinus (Schaeff.: Fr.) Kummer & 52 \\
\hline Lasiosphaeria ovina (Fr.) Ces. et de Not. & 50 \\
\hline Mycena epipterygia (Scop.) S. F. Gray & 46 \\
\hline Ascoeoryne sarcoides (Jacq. ex S. F. Gray) Tul. & 46 \\
\hline
\end{tabular}


Tab. 2 cont.

\begin{tabular}{|c|c|}
\hline 1 & 2 \\
\hline Mycera praccox Vel. & 40 \\
\hline Scleroderma vernicosum Pers. & 40 \\
\hline Sclerodema cirrinum Pers. & 30 \\
\hline Lepioglossum acerosim (Fr.) Moser & 30 \\
\hline Pluteris romellii (Britz) Ssce. & 26 \\
\hline Marasmias rotula (Scop: $\mathrm{Fr}$ ) Fr. & 25 \\
\hline Coprinus patouilliardii Quél. & 23 \\
\hline Mycena pura (Pers.) Kummer & 21 \\
\hline Anirodia malicola (Bark. et Curt.) Donk & 21 \\
\hline Hymenoscyphus fructigenus (Bull. cx Mérat) S. F. Gray & 21 \\
\hline Creopus gelatinosus (Tode: Fr.) Link (- Hypocrea) & 21 \\
\hline Calocera viscosa (Pers: $\mathrm{Fr}$ ) Fr. & 20 \\
\hline Tubaria pellucida (Bull.: Fr.) Gillet & 19 \\
\hline Trichaptum abietimum (Pers.: Fr.) Ryv. & 19 \\
\hline Clitopihus prunulus (Scop.: Fr.) Kummer & 18 \\
\hline Xerocomus chrysenteron (Bull. ex St.-Amans) Quél. & 18 \\
\hline Mycena polygramma (Bull.: Fr.) S. F. Gray & 18 \\
\hline Clitocybe gihba (Pers.: Fr.) Kummer & 18 \\
\hline Cystolepiota sistrata (Fr.) Sing. (=Lepiota semniada) & 18 \\
\hline Usmilna deusia (Fr) Petrak & 18 \\
\hline Merulius tremellosus $\mathrm{Fr}$. & 17 \\
\hline Mollisia melaleaca (Fr.) Sacc. & 15 \\
\hline Calocera viscosa (Pers.: Fr.) Fr. & 15 \\
\hline Collybia dryophila (Pers.: Fr.) Kummer & 15 \\
\hline Laciarius flexwosus (Pers.: Fr.) Fr. & 15 \\
\hline Mycena galericuia (Scop.: Fr.) S. F. Gray & 15 \\
\hline Leptoglossum acerosim (Fr) Moser & 14 \\
\hline Clitocybe fragrans (Sow:: Fr.) Kummer & 14 \\
\hline Inocybe auricoma (Batsch) $\mathrm{Fr}$. & 14 \\
\hline Oudemansiella piatyphylla (Pers.: Fr.) Moser & 13 \\
\hline Mycena alcalina (Fr) Kummer & 13 \\
\hline Hygrophoropsis atariantiaca (Wulf: Fr.) Maire & 13 \\
\hline Mycena parabolica $\mathrm{Fr}_{\mathrm{r}}$ & 13 \\
\hline Inocybe grophylla (Sow: Fr.) Kummer & 13 \\
\hline Hygrophorus camarophyllus (Alb. et Schw: Fr.) Fr. & 12 \\
\hline Psathyrella atomata (Fr.) Quél. & 10 \\
\hline Psathyrella obtusaia (Fr) A. H. Smith & 10 \\
\hline Cystoderma amianthimum (Scop.: Fr.) Fayod & 10 \\
\hline Delicatula integrella (Pers.: Fr.) Fayod & 10 \\
\hline Phatets romellit (Britz.) Sacc. & 10 \\
\hline Macrolepiota rachodes (Vill.) Sing. & 9 \\
\hline Laciaritis glyciosmus $\mathrm{Fr}$. & 9 \\
\hline Postia caesia (Schaefl: Fr.) Karst. & 9 \\
\hline Mycena zephirus (Fr.: Fr.) Kummer & 9 \\
\hline Plutews salicinus (Pers: Fr.) Kummer & 9 \\
\hline Lepista nebudaris (Fr.) Harmaja & 9 \\
\hline Hemimycena cucullata (Pers: Fr.) Sing. & 8 \\
\hline
\end{tabular}


Tab. 2 cont.

\begin{tabular}{|c|c|}
\hline 1 & 2 \\
\hline Coprinus patouilliardii Quẻl. & 7 \\
\hline Pholiota gummosa (Lasch) Sign. & 7 \\
\hline Trametes pubescens (Schum.: Fr.) Pilàt & 7 \\
\hline Inocybe asterespora Quèl. & 7 \\
\hline Coprinus atramentarius (Bull. $\mathrm{Fr}$.) Fr. & 7 \\
\hline Pluteus phicbophorus (Dittmar.: Fr.) Kummer & 7 \\
\hline Mycena hiemalis (Osbeck: Fr.) Quél. & 7 \\
\hline Clavilina cristata (Fr.) Schroeter & 6 \\
\hline Amanita citrina (Schaeff.) S. F. Gray & 6 \\
\hline Laccaria amethystina (Bolt. ex Hooker) Murr. & 6 \\
\hline Mycena atarantiomarginata (Fr.) Quél. & 6 \\
\hline Tremella mesenterica Retz ex Hook & 6 \\
\hline Phellines igniarius (L.: Fr.) Quél. & 6 \\
\hline Hymenochaete rubiginosa (Dickson: Fr.) Lev. & 6 \\
\hline Entoloma sericctum (Bull. ex Merat) Quél. & 5 \\
\hline Macrolepiota procera (Scop.: Fr.) Sing. & 5 \\
\hline Hypholoma fasciculare (Huds:: Fr.) Kummer & 5 \\
\hline Cortmartis saniesus (Fr.) Fr. & 5 \\
\hline Humaria hemisphaerica (Wiggers: Fr.) Fuckel & 5 \\
\hline Pholiota squarrosa (Pers.: Fr.) Kummer & 5 \\
\hline Coprinus lagopus Fr. & 4 \\
\hline Psaihyrella eonopilea (Fr.) Pears ex Dennis & 4 \\
\hline Stropharia albo-cyanea (Desm.) Quél. Fr. & 4 \\
\hline Hebelama sinapizans (Paulet: Fr) Gillet & 4 \\
\hline Paxillus panuaides $\mathrm{Fr}$. & 4 \\
\hline Hygrophorses pustularus (Pers.: Fr.) Fr. & 4 \\
\hline Conocybe tenera (Schaeff: Fr) Kummer & 3 \\
\hline Mycena flavaalba (Fr) Quél. & 3 \\
\hline Pseudoclitocybe cyathiformis (Bull. Fr.) Sing. & 3 \\
\hline Russula fraglits (Pers: Fr.) Fr. ss. Schaeff. & 3 \\
\hline Scutellinia seutellata (L.: Fr.) Gillet & 3 \\
\hline Psilocybe inquilina (Fr. Fr.) Bres. & 3 \\
\hline Xeromphalina campaneila (Batsch: Fr.) Maire & 3 \\
\hline Pholiota dealbata (Scop.: Fr.) Kummer & 3 \\
\hline Conocybe cryprocystis (Atk.) Sing. & 3 \\
\hline Coprimus stercoreus (Bull) Fr. ss, K. et R. & 3 \\
\hline Corrinarius delibutus $\mathrm{Fr}$. & 3 \\
\hline Mycena erubescens Hochnel & 3 \\
\hline Russula heterophylla (Fr.) Fr. & 3 \\
\hline Tubaria furfuracea (Pers: Fr.) Gillel & 3 \\
\hline Psathyrella gracilis (Fr.) Quel. & 3 \\
\hline Crepidotus sphaerosporus (Pat.) Lge & 3 \\
\hline Galerina triscopa (Fr.) Kühn. & 3 \\
\hline Russula versicolor Schacf. & 3 \\
\hline Conocybe tenera (Schaeff: Fr.) Kummer & 3 \\
\hline Mycena flavoalba $\left(\mathrm{Fr}_{\mathrm{r}}\right)$ Quél. & 3 \\
\hline Pluteus pellitus (Pers:; Fr.) Kummer & 3 \\
\hline
\end{tabular}


Tab. 2 cont.

\begin{tabular}{|c|c|}
\hline 1 & 2 \\
\hline Hebeloma crustuliniformis (Bull. ex St.Amans) Quél. & 2 \\
\hline Psathyrella orbitarton (Romagn.) Moser & 2 \\
\hline Xylobolus frustulatus (Pers.: Fr.) Boidin & 2 \\
\hline Mycena viridimarginata (Karst.) & 2 \\
\hline Mycena mucor (Batsch: Fr.) Gillet & 2 \\
\hline Pholiotina aporos (K. v. W.) Clc. (-togularis ss. Lge.) & 2 \\
\hline Pholiota niberculasa (Schaeff.: Fr.) Kummer & 2 \\
\hline Tricholoma populinum Lge. & 2 \\
\hline Polyporus ciliatus Fr: $\mathrm{Fr}$. & 2 \\
\hline Polyporus squamosus Huds.: $\mathrm{Fr}$. & 2 \\
\hline Polyporus varius Pers: Fr. & 2 \\
\hline Agrocybe praecox (Pers.: Fr.) Fayod & 2 \\
\hline Clitopilus prumulus (Scop: $\mathrm{Fr}_{\text {.) }}$ Kummer & 2 \\
\hline Coprimus ephemerus (Bull: Fr.) Fr. & 2 \\
\hline Enioloma nidorosiam (Fr.) Quel. & 2 \\
\hline Gyroporus castaness (Bull:: Fr.) Quél. & 2 \\
\hline Hemimycena cucullata (Pers.: Fr.) Sing. & 2 \\
\hline Hypholoma capnotdes ( $\left.\mathrm{F}_{\mathrm{r} .}\right)$ Kummer & 2 \\
\hline Mycena stylobates (Pers:: Fr.) Kummer & 2 \\
\hline Panellus stypticus (Bull: Fr.) Kummer & 2 \\
\hline Rickenella setipes (Fr.) Raith. & 2 \\
\hline Stropharia semiglobata (Batsch.: Fr.) Quél. & 2 \\
\hline Amanita phalloides (Vaill: Fr.) Secr. & 2 \\
\hline Amanita raginata (Bull: Fr.) Quèl. & 2 \\
\hline Tricholomopsis rutilans (Schaeff: Fr.) Sing. & 2 \\
\hline Entoloma sericellum (Bull.: Fr.) Kummer & 2 \\
\hline Pholionina filaris ( $\mathrm{Fr}_{\mathbf{r}}$ ) Sing. & 2 \\
\hline Mycena virilts (Fr.) Quél. & 2 \\
\hline Galerina badipes (Fr.) Kühn. & 2 \\
\hline Marasmiellns vaillantit (Pers:- Fr.) Sing. & 2 \\
\hline Bolenis edulis Fr. & 1 \\
\hline Clitocyhe cerussata (Fr.) Kummer & 1 \\
\hline Ensoloma clypeatum (L.: Fr.) Kummer & 1 \\
\hline Enfoloma mougeotii (Quél.) Hesler & 1 \\
\hline Entoloma sinuatum (Bull.: Fr.) Kummer & 1 \\
\hline Entoloma subradiatum Kühn et Romagn. & 1 \\
\hline Entoloma rhodocylix (Lasch.: $\mathrm{Fr}_{\mathrm{r}}$ ) Moser & 1 \\
\hline Hebeloma pumilam Lge & 1 \\
\hline Hyphoderma puberum (Fr.) Wallr. (= Peniophora) & 1 \\
\hline Cystoderma carcharias (Pers.: Secr.) Fayod & 1 \\
\hline Cystoderma granulosun (Batsch: Fr.) Kummer & 1 \\
\hline Oudemansiella radicata (Relh.: Fr.) Sing. & 1 \\
\hline Leptopodia atra (König: Fr.) Boud. & 1 \\
\hline Coprinus micaceus (Bull: $\mathrm{Fr}$ ) $\mathrm{Fr}$. & 1 \\
\hline Amanita fulva Schaeff: Pers. & 1 \\
\hline Galerina laevis (Pers.) Sing. & 1 \\
\hline Galerina unicolor $(\mathrm{Fr}$ ) Sing. & 1 \\
\hline
\end{tabular}


Tab. 2 cont.

\begin{tabular}{|c|c|}
\hline 1 & 2 \\
\hline Mycena corricola (Pers.: Fr.) Quél. & 1 \\
\hline Hyphoderma radula $\left(\mathrm{Fr}_{\mathrm{r} .:} \mathrm{Fr}_{\mathrm{r}}\right.$ ) Donk & 1 \\
\hline Lactarius blennius $\mathrm{Fr}$. & 1 \\
\hline Peziza varia $(\mathrm{Hedw}) \mathrm{Fr}$. & 1 \\
\hline Pholiota destriens (Brond.) Quél. & 1 \\
\hline Pluteus atrotomentostas (Konr.) Kühn. & 1 \\
\hline Russula aiutaced (Pers: $\mathrm{Fr}$ ) $\mathrm{Fr}$. & 1 \\
\hline Russula pecinata $\mathrm{Fr}$. & 1 \\
\hline Russula vitellina (Pers.) Fr. & 1 \\
\hline Simocybe centunculus (Fr.) Sign. & 1 \\
\hline Steccherinum ochraceum (Pers: Fr.) S. F. Gray & 1 \\
\hline Mycena speira (Fr:: Fr) Gillet & 1 \\
\hline Cortinarius privignus $\mathrm{Fr}$. & 1 \\
\hline Lactarius piperatus (L.: $\mathrm{F}_{\mathrm{r}}$ ) S. F. Gray & 1 \\
\hline Tricholoma sulphureum (Bull.: Fr.) Kummer & 1 \\
\hline Mycena amygdaiina (Pers.) Sign. (=filopes) & 1 \\
\hline Pholiota hucifera (Lasch) Quél. & 1 \\
\hline Inocybe asterophara Quél. & 1 \\
\hline Mycena pelianihina (Fr) Quél. & 1 \\
\hline Tyramyces lowei (Pilát) Jūlich & 1 \\
\hline Tyromyces kymatodes (Rost. s. Bourd. et G.) Donk & 1 \\
\hline Mycena rubramarginata $\left(\mathrm{Fr}_{\mathrm{r}}\right.$ ) Kummer & 1 \\
\hline Pleurotellus chioneus (Pers.: Fr.) Kühn. & 1 \\
\hline Pluteus ephebeus (Pers: Fr.) Quél. & 1 \\
\hline Russuia delica $\mathrm{Fr}$. & 1 \\
\hline Russuia emerica $\mathrm{Fr}$. & 1 \\
\hline Pycnoporellus fulgens (Fr.) Donk & 1 \\
\hline Polyporus badius (Pers.: S. F. Gray) Schw. & 1 \\
\hline Entomola juncinum (Kühn. et Romagn.) Noord. & 1 \\
\hline
\end{tabular}

\section{Colonisation}

The tree stand on both plots, I and II, was rather healthy, judging by the state of the trees which were in a good condition. Therefore it is not surprising that there were not many fallen branches, although there were some fallen trees, logs and trunks of different ages. However, the fully mature mountain ash tree which fell in summer of 1996 on plot I displayed its illness. Its smooth trunk showed brown rot near its roots. Old spruces, broken half way through their height or lower, were infested by Fomitopsis pinicola. Its fruit-bodies were formed quite high and the fungus grew through old logs that lay on the forest floor up to half of their height in a long, horizontal band. The close contact with the ground, mosses which colonised the logs rapidly, as well as shade (the bands occurred on the northern face) assured 
a moisture level suitable for the mycelium. An association of mosses emerged there which provided an ecological niche for the development of small, saprotrophic fruit-bodies of Agaricales (e.g. Mycena).

Two fungi with well-formed fruit-bodies, Fomes fomentarius and Ganoderma applanatum, thrived on similar substrates, i.e. deciduous tree wood in an advanced stage of decay. These two parasites, which cause rapid decomposition of wood, are largely responsible for fallen and broken trees and branches and they live as saprotrophes for a long time after the host is dead. Pycnoporus fulgens and Inonotus rheades appeared in spring and summer for a one-year period. Other Aphyllophorales species with small fruit-bodies occurring individually or in small, overlapping clutches, as well as some sac fungi, such as Xylaria longipes thrived on thin, but still firm twigs or humifying logs.

One of Agaricales, Armillaria mellea, a well-known forest parasitic fungus which qualifies here as a saprotroph, was found only twice in rather small quantities (less than 15 individuals) and always on the ground.

Multifructificating fungi with fleshy fruit-bodies, including Armillaria mellea are so-called terrestrial species. However, they can find suitable substrates on decaying timber found in the forest. Since the partially rotten wood is usually covered by ground flora or is shaded, it provides good conditions for the fungi to thrive. Amongst those species the cold-resistant Kuehneromyces mutabilis can always be found in autumn, while Hypholoma fasciculare is considered a dominating species in early and full autumn ( $\mathrm{L}$ is i e w s k a and C e $1 \mathrm{k}$ a 1995). They were both not found by Nespiak. Both in his studies and on plots I and II Pluteus romellit and P. cervinus were commonly found. Also Strobilurus esculentus was found everywhere on spruce cones buried in the ground in both of our studies.

The actual terrestrial macromycetes are found on the ground, but their mycelia develop in deeper layers of soil, where its moisture is high enough to allow for the production of large fruit-bodies. Mycelia forming fruit-bodies develop less deeply, closer to the surface of the ground which is frequently covered by fallen leaves. In order for the fruit-bodies to develop, the moisture (sufficient rainfall) of the soil and air is not the only necessary factor. The process also requires suitable temperature and proper light, which, however, cannot be full sunlight. Some such fungi produce rhizomorphic strands or rhizomorphs (e.g. Marasmius rotula or Lycoperdon pyriforme) which penetrate the substrate and are found on all plots. Also a small group of coprophilous fungi can be found. Since they depend on a quickly drying substrate (roe deer and wild boar droppings) they do not last for long and hence they can be called ephemerids.

The occurrence of other coprophilous fungi of the Coprinus genus could be expected due to the proximity of the agricultural field. However, the dense 
protection zone of the Park doesn't let their spores spread. Also worth noting is the lack of species that prefer open areas and cope with direct sunlight or shading by small herbs (e.g. of the genus Hygrocybe). Also other species that could have got here from other divisions where various associations of vascular plants dominate are not found here.

Mycelia of species that form larger fruit-bodies spread in the humus-rich soil easily and widely. Hyphae of some fungi penetrate the substrate and establish symbiotic contacts mainly with roots of trees. These are the so-called mycorrhizal fungi. In numerous papers they are described as summer and autumn terrestrial fungi which produce large fruit-bodies sought for by mycophages. They live together with coniferous and deciduous trees alike.

\section{Mycorrhizal species}

While analysing the collection list it appeared that there were 39 species in common. They occur on plots I and II and they were also recorded earlier by Nespiak. The list includes all common mycorrhizal species. Only at this stage apparent differences between our collections were revealed. Nespiak found 16 species of those listed in Table 3, of which only 6 were found again. Almost 40 years later there were twice as many of those species found on plots I and II, including the 6 that were found again. The proportion $2: 1$ was sustained, similarly as in the case of the general number of all fungi listed.

Table 3

Comparison of numbers of species within ecological groups

\begin{tabular}{|c|c|c|c|c|c|}
\hline & 1994 & \multicolumn{2}{|c|}{1995} & \multicolumn{2}{|c|}{1996} \\
\hline $\begin{array}{l}\text { Plots } \\
\text { Groups }\end{array}$ & $(I+I I)$ & I & II & 1 & II \\
\hline $\begin{array}{l}\text { Mycorrhizal } \\
\text { Saprotrophes } \\
\text { Parasites }\end{array}$ & $\begin{array}{r}16 \\
66 \\
4\end{array}$ & $\begin{array}{r}14 \\
83 \\
3\end{array}$ & $\begin{array}{r}20 \\
70 \\
3\end{array}$ & $\begin{array}{r}14 \\
58 \\
4\end{array}$ & $\begin{array}{r}12 \\
56 \\
6\end{array}$ \\
\hline Total & 86 & 100 & 93 & 76 & 74 \\
\hline
\end{tabular}

Ta ble 4

Differences between the previous and current collections

\begin{tabular}{|l|c|c|c|}
\hline & $1994-1996$ collection & Common & Nespiak (1959) collection \\
\hline Boletales & 5 & 1 & 1 \\
Russuiales & 17 & 1 & 4 \\
Sclerodiermatales & 2 & - & - \\
Agaricales & 23 & 4 & 11 \\
\hline Total & 37 & 6 & 16 \\
\hline
\end{tabular}


As it can be seen, in this case general ecological factors influence both saprotrophs and mycorrizal fungi in the same degree. K a l a m e e s (1980) gives similar results from Estonia. He states that mycobionts are the group of Agaricales that is the richest in trophic species, including as many as $39 \%$ of all the groups found in that country.

Mycobionts react to water shortages much less than common saprotrophs. Having established connections with the roots of their co-symbionts they obtain the moisture necessary to survive. Their fruit-bodies reduce their growth rate, their hyphae loose their elasticity, their caps wind up and present the hymenophores. However, as soon as rains start the fungi quickly return to their previous shape. The smaller the fruit-bodies the sooner they regain their normal shape (e.g. Laccaria laccata). An important part is played by the surroundings, which are small ground plants. They also encounter potential competitors for symbiotic partners of the same type. They can also differ in the period of forming fruit-bodies during a season or during vegetation periods.

The differences in the rhythm of fructification of some species of terrestrial fungi observed ( $\mathrm{G}$ u m i n s k a 1991/1992). The pic fructification occurred in the second part of September 1996 year or in the first part of October.

Within the mycorrhizal fungi group on my both plots three species are worth noting, which occur most often and for longest periods. These species are:

Lactarius quiefus (fr. 14/2),

Laccaria laccata (fr. 15/2)

as well as one that gives the studied area a real character Paxillus involutus (fr. 8/2).

Xerocomus chrysenteron (fr. 13/2), which forms symbiotic links with deciduous trees, mainly not very old hornbeam, is represented less richly. All of them were found near oaks. K a 1 a m e e s'es (1980) opinion is also worth mentioning. He considers Laccaria laccata a facultatively mycorrhizal species.

\section{Fruiting intensity and weather conditions}

The influence of periodic moisture conditions on the fruiting of the fungi found also has to be discussed. Lactarius quietus and Laccaria laccata were the mycorrhizal dominants in 1996. Amongst saprotrophic species Bisporella citrina dominated. It occurred in large numbers and in clusters ( 503 individuals on plot I and 138 individuals on plot II). During the first period of my studies there was a long drought in Poland during summer months. It stopped the development of macromycetes almost completely. They started appearing in the eastern part of the country after small rains (on August $30^{\text {th }} \mathrm{I}$ only found 15 
species). Despite some rains in September, the forest floor was not water soaked properly and it remained dry. In October, the just starting development of fruit-bodies was halted by frost that arrived too early $\left(-3^{\circ} \mathrm{C}\right.$ on October $\left.19^{\text {th }}\right)$. The second study period was characterised by a long and cold spring and the fruit-bodies appeared rapidly after a warm storm in May. The situation was similar in 1996, but drought and rain periods were spread differently, which influenced the timing of fungi appearance.

\section{SUMMARY AND CONCLUSIONS}

1. The fungi of the Białowieza Forest, the National Park in particular, have not been analysed in terms of their trophy so far. Only $\mathrm{N}$ e s p i a k (1959) carried out a large-scale study concerning fungi on $100 \mathrm{~m}^{2}$ plots in six different plant associations.

2. During the 40 years the composition of vascular plants did not change significantly.

3. This work's aim was to compare possible changes in macromycetes occurring in the forest in the same plant associations in which Nespiak worked, as well as to carry out a similar study but on larger plots $\left(1000 \mathrm{~m}^{2}\right)$ and only in one association. Tilio-Carpinetum.

4. Altogether, Nespiak found 109 species on his plots (here treated as one), while 1 found 215 , i.c. almost twice as many. Such big a difference may be a result of climatic conditions in the seasons that the fungi were collected, the size of the plots and the mycelium's adjustment to the fruiting time.

5. Due to the way Nespiak treated the subject, who mainly concentrated on Agaricales producing large fruit-bodies, I also limited my collection list and analysis to the representatives of this order, in order to make comparisons easier. Nespiak's list "adjusted" in such way included 175 species. It revealed a 5:1 ratio in favour of the present time, since 34 species were common for Nespiak and for me. This fact suggested that there is certain stability in the macromycetes group in Tilio-Carpinetum in the Białowieża National Park.

6. Saprotrophs occurred evenly. In all the plots (Nespiak's, I and II) they included Pluteus cervinus, $P$. romellii and Strobilurus esculentus (due to the presence of buried spruce cones), Marasmius rotula, Lycoperdon pyriforme. There were almost none coprophilous, ephemeric Coprimus species. Also species that prefer open areas did not occur.

7. Each plot revealed the presence of the same 4 parasites.

8. Thirty two species of mycorrhizal fungi were found on each plot (I and II), which, in comparison to saprotrophs, amounted $21.1 \%$ (I) and $20.4 \%$ (II). 
9. The new study plots were 10 times larger and relatively more fungi were collected there.

10. The September-October period was the richest in terms of species diversity, since the forest provided enough warmth then. During all the visits Lactarius quietus and Paxillus involutus were found. These fungi, as well as Laccaria laccata appeared the earliest and lasted the longest. It seems strange that Nespiak did not ever encounter the strongly oakconnected Lactarius quietus, which he did find in other divisions.

11. Most saprotrophes on I and II plots are not, as it seems, connected with herbaceous plants that grow there. They were found in different periods as single, dispersed individuals. Only the occurrence of Strobilurus esculentus depended on fallen cones of an old spruce.

12. Most unfavourable conditions that halted the development of mycelia of small saprotrophs were created by a long-lasting drought. Mycorrhizobionts with large fruit-bodies managed to adjust to it properly by benefiting from their symbiotic partners.

13. Due to the high diversity of species that require different conditions we still have certain doubts. Finding five times more species, including only 34 common species out of 131 , after 40 years indicates the necessity of further penetration of Tilio-Carpinetum patches in the Bialowieza National Park.

14. The three-year study period is too short for monitoring fungi due to, for example, changing climatic conditions.

I wish to express my gratitude to Prof. J. Falinski (Bialowieża Geobotanical Station of Warsaw University) for his help with establishing two plots in forest division and Prof. J. Jakubowska-Gabara (University of Łódź) for preparing floristic-phytosociological characteristic of the study plots.

\section{REFERENCES}

B loński F., Drym mer K, Ejs mond A. 1888. Sprawozdanie z wycieczi botanicznej odbytej do Puszczy Białowieskiej w lecie 1887. Pam. Fizjogr. 8, 3: 59-155.

B to t s k i F. Dry m mer K. 1889. Sprawozdanie z wycieczki botanicznej odbytej do Puszczy Bialowieskiej, Ladzkiej i Świsloskiej w 1888 roku. Pam. Fizjogr. 9, 3: 55-115.

Fa 1 i ńs k i J. 1998. La foret et son milieu. In: Braun-Blanquetia 20: 21-47. Camerino.

$\mathrm{F}$ a 1 i i s $\mathrm{k}$ i J., M u le $\mathrm{n} \mathrm{k} \mathrm{o} \mathrm{W.} \mathrm{(ed.)} \mathrm{1992.} \mathrm{Cryptogamous} \mathrm{plants} \mathrm{in} \mathrm{the} \mathrm{forest} \mathrm{communities} \mathrm{of}$ Bialowieża National Park. Check-list of cryptogamous and seminal plant species recorded during the period 1987-1991 on the permanent plot V-100 (Project CRYPTO [1]) Phytocoenosis 4 (N.S.) Archiv. Geobot: 3: 1-11.

G u m inska B. 1991/1992. Higher fungi of the Tilio-Carpinetum forest association in the Skolczanka Reserve near Cracow. Acta Mycol, 27 (1): 137-158.

J a k u b o w s a-G a b a I a J. 1996. Phytosociological documentation of permanent plots in Poland. In: R. F e 11 n er, M. L a wry now i cz, C. P e r in i, Mycological monitoring in European oak forests-the pilot project (msc.). 
K a 1 a m e es K. 1980. Trophic groups of Estonian agarics. In: Ecology and distribution of fungi: $71-98$.

N espia k A. 1955. Grzyby kapeluszowe w zespolach leśnyeh Puszczy Bialowieskiej (komunikat wstepny). Fragm. Flor. Geobot. 2 (2): 134-145.

Nespia k A. 1959. Studia nad udzialem grzybów kapeluszowych w zespolach lesnych na terenie Białowieskiego Parku Narodowego, Monogr. Bot. 8: 3-141.

Przy b y 1 K. 1995. Zamicranie dębow w Polsce. Idee ckologiezne 8 (4): 3-85. Poznan. S k i r g i e 11 o A. 1988. Polska bibliografia mikologiczna L. Bibliografia botaniczna 2 Instytut Botaniki im. W. Szafera PAN, PWN, Warszawa.

\section{Macromycetes Bialowieskiego Parku Narodowego - studia monitoringowe}

\section{Streszezenic}

Obserwacje mikologiczne prowadzono w latach 1994-1996 na dwóch stalych powierzchniach w Tilio-Carpinetum na terenic Białowieskiego Parku Narodowego. Projekt realizowany był przy międzynarodowej wspólpracy w ramach programu „Mycological monitoring in European oak forcsts" w odpowiedzi na sygnaly o zagrożeniu dẹbów na naszym kontynencie. Blisko 40 lat temu Andrzej Nespiak prowadzil mikosocjologiczne badania w tym samym zespole, na tych samych powierzchniach. Badania koncentrowaty się na grzybach naziemnyeh, głównie Boletales 1 Agaricales, gatunkach mikoryzowych i saprotroficnnych. Zebrano łącznie 215 gatunków, ale tylko 34 byly wspólne w badaniach obojga autorów. Wykazano gatunki dominujące w grupie grzybów mikoryzowych. 